\title{
ANGKA KEJADIAN DAN KARAKTERISTIK ANEMIA PADA PASIEN YANG BEROBAT DI KLINIK PRATAMA UIN SUNAN AMPEL SURABAYA
}

\author{
Dwi Rukma Santi \\ Fakultas Psikologi dan Kesehatan UIN Sunan Ampel Surabaya \\ Email: dwirukmasanty@uinsby.ac.id; dwirsanty@gmail.com
}

\begin{abstract}
ABSTRAK
Anemia adalah suatu keadaan yang menunjukkan bahwa kadar hemoglobin dalam sel darah merah berada di bawah normal. Anemia defisiensi besi masih merupakan salah satu masalah gizi utama di Indonesia, disamping kekurangan kalori protein, vitamin A dan yodium. Tujuan penelitian ini adalah untuk mendeskripsikan kejadian dan karakteristik anemia pada pasien yang berobat ke Klinik Pratama UIN Sunan Ampel Surabaya Periode Tahun 2014-2015. Penelitian ini merupakan studi deskriptif dengan bahan penelitian berupa data rekam medis pasien anemia di Klinik Pratama UIN Sunan Ampel Surabaya periode tahun 2014 - 2015. Hasil menunjukkan bahwa angka kejadian anemia 22\%. Karakteristik anemia berdasarkan usia paling banyak terjadi pada kelompok usia reproduksi sehat (20 - 30 tahun) yaitu sebanyak 211 pasien (51,30\%), berdasarkan jenis kelamin lebih banyak terjadi pada perempuan, yaitu 344 pasien (83,70\%), tempat tinggal sebagian besar adalah tinggal di kost/pondok/asrama, yaitu 293 pasien (71,28\%), dan keluhan subyektif tersering adalah mudah lelah, yaitu 358 pasien (87,10\%). Dapat disimpulkan bahwa peningkatan kesadaran civitas akademik untuk hidup sehat melalui tindakan promotif maupun preventif sangat diperlukan.
\end{abstract}

Kata Kunci : angka kejadian, karakteristik anemia, anemia

\section{ABSTRACT}

Anemia is a condition that indicates the level of hemoglobin in red blood cells is below normal. Iron deficiency anemia is still one of the main nutritional problem in Indonesia, the addition to lack of calories of protein, vitamin A and iodine. The purpose of this study was to describe incidence and characteristics of anemia in patients treated at the Clinic Primary UIN Sunan Ampel Surabaya Period 2014-2015. This research is a descriptive study with research material in the form of medical records of patients at the Clinic Primary anemia UIN Sunan Ampel Surabaya period 2014 - 2015. The results show that the incidence of anemia $22 \%$. Characteristics of anemia by age most occur in healthy reproductive age group (20-30 years) as many as 211 patients (51.30\%), based on sex is more common in women, 344 patients (83.70\%), shelter most are living in the boarding house / boarding, 293 patients (71.28\%), and subjective complaints of fatigue is the most common, namely 358 patients (87.10\%). It can be concluded that the increased awareness of the academic community to live healthy through promotive and preventive action is needed.

Keywords: incidence, characteristics of anemia, anemia

\section{PENDAHULUAN}

Pembangunan kesehatan di Indonesia saat ini dihadapkan pada dua masalah, pada salah satu pihak penyakit menular masih merupakan masalah kesehatan masyarakat yang belum banyak tertangani, di lain pihak telah terjadi peningkatan kasus-kasus penyakit tidak menular yang banyak disebabkan oleh gaya hidup akibat urbanisasi, modernisasi, dan globalisasi.
Anemia adalah suatu keadaan yang menunjukkan bahwa kadar hemoglobin dalam sel darah merah berada di bawah normal. Pada pria kadar hemoglobin normal adalah 13-17 gr\%. Sedangkan pada wanita, hemoglobin normal adalah 12-16 gr\%. Sel darah merah mengandung hemoglobin yang mengangkut oksigen dari paruparu dan mengantar ke seluruh tubuh. Anemia juga dapat dikatakan bilamana ukuran dan jumlah 
eritrosit dalam hemoglobin kurang dari normal. Beberapa kelompok yang rentan terhadap anemia adalah anak-anak, remaja, kelompok ibu hamil dan usia lanjut.

Anemia defisiensi besi masih merupakan salah satu masalah gizi utama di Indonesia, disamping kekurangan kalori protein, vitamin A dan yodium. Insiden anemia defisiensi besi di Indonesia adalah $40,5 \%$ pada balita; $47,2 \%$ pada usia sekolah; $57,1 \%$ pada remaja putri dan $50,9 \%$ pada ibu hamil. Zat besi selain dibutuhkan untuk pembentukan hemoglobin yang berperan dalam penyimpanan dan pengangkutan oksigen, juga terdapat dalam beberapa enzim yang berperan dalam metabolisme oksidatif, sintesis DNA, neurotransmitter dan proses katabolisme serta perkembangan anak.

Klinik Pratama UIN Sunan Ampel (Klinik UINSA) adalah klinik yang berada di lingkungan perguruan tinggi UIN Sunan Ampel Surabaya yang pada hakikatnya merupakan bagian integral dari suatu perguruan tinggi. Klinik UINSA ini bersama-sama dengan unit kerja lainnya dan dengan peran yang berbeda-beda, bertugas membantu seluruh mahasiswa dan civitas akademik untuk tetap sehat baik jasmani maupun rohani. Saat ini mahasiswa UINSA berjumlah \pm 9192 orang, tenaga dosen berjumlah \pm 505 orang, tenaga kependidikan/administrasi berjumlah \pm 254 orang. Jumlah kunjungan pasien Klinik UINSA berkisar antara $1600-1900$ pasien pertahun. ${ }^{8}$

Berdasarkan laporan tahunan Klinik UINSA 2014 dan 2015 menunjukkan bahwa jumlah kasus anemia mengalami peningkatan dan anemia menempati urutan ke-3 pada 10 kasus penyakit terbanyak. Pada tahun 2014 kasus anemia berjumlah 195 orang $(10,2 \%)$ dari total kunjungan (1910 orang) dan pada tahun 2015 kasus anemia berjumlah 216 orang $(11,8 \%)$ dari total kunjungan (1826 orang). Hal tersebut menunjukkan bahwa kasus anemia di Klinik UINSA cenderung mengalami peningkatan.

Penderita dengan anemia dapat terganggu kegiatan sehari-harinya. Adapun gejala yang sering muncul antara lain: pusing, lemah, letih, lelah, dan lesu. Akan tetapi, kadang-kadang anemia tidak menimbulkan gejala yang jelas, misalnya mudah lelah bila berolahraga, sulit konsentrasi, dan mudah lupa. Selain itu, anemi juga dapat mengakibatkan penurunan daya tahan tubuh sehingga mudah terkena infeksi. Bahkan, prevalensi anemia yang tinggi dikalangan remaja jika tidak tertangani dengan baik akan berlanjut hingga dewasa dan berkontribusi besar terhadap angka kematian ibu, bayi lahir prematur, dan bayi dengan berat lahir rendah.

Penelitian ini bertujuan untuk mendeskripsikan kejadian dan karakteristik anemia pada pasien yang berobat ke Klinik UINSA Periode Tahun 2014-2015, karena anemia merupakan urutan ketiga dari 10 penyakit terbanyak yang ada di Klinik UINSA.

\section{TUJUAN PENELITIAN}

Penelitian ini bertujuan untuk mendeskripsikan kejadian dan karakteristik anemia pada pasien yang berobat ke Klinik Pratama UIN Sunan Ampel Surabaya Periode Tahun 2014-2015, antara lain: a. mengidentifikasi karakteristik usia pasien anemia, b. mengidentifikasi karakteristik jenis kelamin pasien anemia, c. mengidentifikasi karakteristik tempat tinggal pasien anemia, d. mengidentifikasi karakteristik jenis keluhan anemia.

\section{KAJIAN PUSTAKA}

Anemia adalah keadaan berkurangnya jumlah eritrosit atau hemoglobin (protein pembawa O2) dari nilai normal dalam darah sehingga tidak dapat memenuhi fungsinya untuk membawa O2 dalam jumlah yang cukup ke jaringan perifer sehingga pengiriman $\mathrm{O} 2 \mathrm{ke}$ jaringan menurun.

Secara fisiologi, harga normal hemoglobin bervariasi tergantung umur, jenis kelamin, kehamilan, dan ketinggian tempat tinggal. Oleh karena itu, perlu ditentukan batasan kadar hemoglobin pada anemia. Seperti yang tertera pada tabel 1 berikut ini :

Tabel 1. Batasan Kadar Haemoglobin Berdasarkan Usia

\begin{tabular}{|c|c|c|}
\hline Kelompok & Umur & $\begin{array}{l}\text { Haemoglobin } \\
\text { (g/dl) }\end{array}$ \\
\hline \multirow{2}{*}{ Anak } & $\begin{array}{l}6 \text { bulan }-6 \\
\text { tahun }\end{array}$ & $<11$ \\
\hline & $\begin{array}{l}6 \text { tahun }-14 \\
\text { tahun }\end{array}$ & $<12$ \\
\hline \multirow{5}{*}{ Dewasa } & Wanita & $<12$ \\
\hline & Dewasa & \\
\hline & Laki-laki & $<13$ \\
\hline & Dewasa & \\
\hline & Ibu Hamil & $<11$ \\
\hline
\end{tabular}

Sumber : WHO,2011 


\section{METODE PENELITIAN}

Penelitian ini merupakan studi deskriptif dengan bahan penelitian berupa data rekam medis pasien anemia di Klinik Pratama UIN Sunan Ampel Surabaya periode tahun 2014 - 2015. Pengambilan data diperoleh melalui data sekunder yaitu rekam medis rawat jalan pasien yang didiagnosis anemia di Klinik Pratama UIN Sunan Ampel Surabaya periode tahun 2014 - 2015. Waktu pengambilan data dilakukan pada bulan Februari - Maret 2016.

\section{HASIL PENELITIAN}

1. Kejadian Anemia Berdasarkan Kadar Haemoglobin

Tabel 2. Distribusi Frekuensi Kejadian Anemia Berdasarkan Kadar Haemoglobin

\begin{tabular}{|c|c|c|}
\hline $\begin{array}{l}\text { Kadar } \\
\text { (g/dl) }\end{array}$ & Hb $f$ & $\%$ \\
\hline 10,50 & 59 & 14,40 \\
\hline 10,60 & 15 & 3,60 \\
\hline 10,80 & 37 & 9,00 \\
\hline 11,00 & 145 & 35,30 \\
\hline 11,20 & 76 & 18,50 \\
\hline 11,50 & 49 & 11,90 \\
\hline 11,80 & 10 & 2,40 \\
\hline 12,00 & 20 & 4,90 \\
\hline Jumlah & 411 & 100 \\
\hline
\end{tabular}

Mean $=11,06 \quad$ Me $=11 \quad$ Min $=10,50 \quad$ Max $=$ 12

Tabel 2 menunjukkan bahwa pada umumnya pasien mempunyai kadar haemoglobin $(\mathrm{Hb})$ $11,06 \mathrm{~g} / \mathrm{dl}$, dengan kadar $\mathrm{Hb}$ terendah adalah $10,50 \mathrm{~g} / \mathrm{dl}$ dan tertinggi $12 \mathrm{~g} / \mathrm{dl}$. Hampir sebagian $(35,30 \%)$ pasien anemia mempunyai kadar $\mathrm{Hb}$ $11,0 \mathrm{~g} / \mathrm{dl}$.

2. Karakteristik Umur Pasien Anemia

Tabel 3. Distribusi Frekuensi Karakteristik Umur Pasien Anemia

\begin{tabular}{lll}
\hline Umur & $\boldsymbol{f}$ & \% \\
\hline$<20$ tahun & 174 & 42,30 \\
$20-30$ tahun & 211 & 51,30 \\
$>30$ tahun & 26 & 6,40 \\
\hline Jumlah & 411 & 100 \\
\hline
\end{tabular}

Mean $=21,07 \quad$ Me $=20 \quad$ Min $=18 \quad$ Max $=41$ Tabel 3 menunjukkan bahwa pada umumnya pasien yang mengalami anemia berumur 21 tahun, dengan umur termuda 18 tahun dan umur tertua
41 tahun. Sebagian $(51,30 \%)$ pasien yang mengalami anemia adalah kelompok umur 20 30 tahun.

3. Karakteristik Jenis Kelamin Pasien Anemia Tabel 4. Distribusi Frekuensi Karakteristik Jenis Kelamin Pasien Anemia

\begin{tabular}{lll}
\hline Jenis Keluhan & $\boldsymbol{f}$ & \% \\
\hline Laki-laki & 67 & 16,30 \\
Perempuan & 344 & 83,70 \\
\hline Jumlah & 411 & 100 \\
\hline
\end{tabular}

Tabel 4 menunjukkan bahwa sebagian besar $(83,70 \%)$ pasien yang mengalami anemia adalah perempuan.

4. Karakteristik Tempat Tinggal Pasien Anemia Tabel 5. Distribusi Frekuensi Karakteristik Tempat Tinggal Pasien Anemia

\begin{tabular}{lll}
\hline Tempat Tinggal & $\boldsymbol{f}$ & $\mathbf{\%}$ \\
\hline Kost/Pondok/Asrama & 293 & 71,28 \\
Rumah Orangtua & 118 & 28,72 \\
\hline Jumlah & 411 & 100 \\
\hline
\end{tabular}

Tabel 5 menunjukkan bahwa sebagian besar $(71,28 \%)$ pasien yang mengalami anemia mempunyai tempat tinggal di kost/pondok/asrama.

5. Karakteristik Keluhan Pasien Anemia Tabel 6. Distribusi Frekuensi Keluhan Pasien Anemia

\begin{tabular}{lll}
\hline Keluhan Subyektif & $\boldsymbol{f}$ & $\mathbf{\%}$ \\
\hline Pusing berkunang- & 143 & 34,79 \\
Mata & 244 & \\
kunang & 358 & 87,37 \\
Mudah lelah & 335 & 81,51 \\
Mudah ngantuk & 123 & 29,93 \\
Sulit konsentrasi & 58 & 14,11 \\
Sering pingsan & 28 & 6,81 \\
Lainnya &
\end{tabular}

Tabel 6 menunjukkan bahwa sebagian besar $(87,10 \%)$ keluhan subyektif yang dialami pasien anemia adalah mudah lelah, kemudian diikuti keluhan mudah ngantuk $(81,51 \%)$ dan mata sering berkunang-kunang $(59,37 \%)$. 


\section{PEMBAHASAN}

Parameter yang paling umum digunakan untuk menunjukkan penurunan massa eritrosit adalah kadar hemoglobin. Berdasarkan pengukuran kadar hemoglobin pasien, sebanyak $411(22 \%)$ subjek memiliki nilai kadar hemoglobin antara 10,50-12 $\mathrm{g} / \mathrm{dl}$ dan termasuk dalam kategori anemia. Di Indonesia anemia sebagian besar disebabkan oleh anemia defisiensi besi. Zat besi yang tidak adekuat menyebabkan berkurangnya sintesis hemoglobin sehingga menghambat proses pematangan eritrosit. ${ }^{2,6}$

Zat besi yang tidak adekuat disebabkan oleh rendahnya asupan besi total dalam makanan atau bioavailabilitas besi yang dikonsumsi menurun (makanan banyak serat, rendah daging, dan rendah vitamin C), kebutuhan akan zat besi yang meningkat (pada bayi prematur, anak dalam pertumbuhan, ibu hamil dan menyusui), perdarahan kronis, diare kronik, malabsorbsi, serta infeksi cacing tambang. Angka kejadian anemia pada penelitian ini lebih kecil dari hasil penelitian yang dilakukan di Nepal yaitu sebesar 78,3\%.

Subjek dalam penelitian ini sebagian besar mempunyai umur antara 20 - 30 tahun (51,30\%). Pada usia 20 - 30 tahun merupakan masa reproduksi sehat, dimana pada saat ini kebutuhan zat besi meningkat seiring dengan perkembangan biologis, kognitif maupun emosional. Pasien yang datang untuk periksa ke Klinik UINSA adalah seluruh civitas akademik, yang terdiri dari mahasiswa, dosen, dan seluruh tenaga kependidikan.

Pada tabel 4 menunjukkan bahwa pasien anemia yang datang ke Klinik UINSA sebagian besar adalah perempuan $(83,70 \%)$. Perempuan membutuhkan zat besi yang lebih tinggi karena dibutuhkan untuk mengganti zat besi yang hilang pada saat menstruasi. Sepanjang usia reproduktif, perempuan akan mengalami kehilangan darah akibat menstruasi. Kehilangan darah karena menstruasi yang berat merupakan salah satu penyebab anemia pada perempuan. Selain itu, perhatian perempuan muda/remaja putri terhadap bentuk tubuh yang ideal sangat tinggi, sehingga mereka sering membatasi asupan makannya. Diet yang tidak seimbang dengan kebutuhan zat gizi akan mengakibatkan tubuh kekurangan zat gizi yang penting seperti besi. Oleh sebab itu, perempuan termasuk salah satu kelompok yang berisiko tinggi menderita anemia.

Tempat tinggal dan kebiasaan pola makan juga sangat berpengaruh terhadap kejadian anemia. Perguruan tinggi negeri UIN Sunan
Ampel Surabaya terletak di ibukota propinsi Jawa Timur, yaitu Surabaya. Mayoritas mahasiswa berasal dari luar kota dan daerah. Mereka tinggal jauh dari orangtua dan hidup di kost, pondok, maupun asrama. Dapat dilihat pada tabel 5 bahwa sebagian besar $(71,28 \%)$ pasien yang datang ke Klinik UINSA bertempat tinggal di kost, pondok, maupun asrama. Perhatian perempuan muda/remaja putri terhadap bentuk tubuh yang ideal sangat tinggi, sehingga mereka sering membatasi asupan makannya. Asupan zat gizi dan diet seimbang sangat membantu untuk pencegahan anemia. Dalam penelitian sebelumnya disebutkan bahwa seseorang yang kekurangan protein berisiko 3,48 kali lebih besar untuk mengalami anemia daripada yang tidak mengalami kekurangan protein. Selain itu, kebutuhan akan vitamin $\mathrm{A}$ dan vitamin $\mathrm{C}$ juga dapat membantu absorbsi zat besi sehingga tidak terjadi anemia.

Gejala umum anemia disebut juga sebagai sindroma anemia yang dijumpai pada anemia defisiensi besi apabila kadar hemoglobin turun 11 $\mathrm{g} / \mathrm{dl}$, badan lemah, lesu, cepat lelah, mata berkunang-kunang serta telinga mendenging. Berdasarkan hasil penelitian menunjukkan bahwa sebagian besar $(87,10 \%)$ pasien anemia yang datang ke klinik UINSA mengalami keluhan subyektif mudah lelah, serta mudah mengantuk sehingga sulit berkonsentrasi dalam belajar. Pada pemeriksaan fisik dijumpai pasien yang pucat, terutama pada konjungtiva. Diagnosis yang tepat untuk anemia adalah dengan pemeriksaan kadar haemoglobin dalam darah.

\section{SIMPULAN DAN SARAN}

Dari hasil penelitian tentang angka kejadian dan karakteristik pasien anemia di Klinik UINSA selama periode tahun 2014 - 2015 tersebut adalah 411 pasien dari 3736 kunjungan, dengan kadar haemoglobin terbanyak $11 \mathrm{~g} / \mathrm{dl}$ $(35,30 \%)$, usia jumlah tebanyak pada usia reproduksi sehat 20-30 tahun $(51,30 \%)$, jumlah perempuan lebih banyak dibandingkan laki-laki, mayoritas adalah mahasiswa yang tinggal di kost/pondok/asrama, dan keluhan subyektif tersering yang dialami oleh pasien adalah mudah lelah.

Peningkatan asupan makanan yang mengandung zat besi perlu dilakukan oleh pasien, baik dari segi kualitas maupun kuantitas serta mengkonsumsi suplemen zat besi secara rutin ketika mengalami gejala anemia dan khususnya pada perempuan saat menstruasi. Selain itu, 
perlunya pengadaan penyuluhan ataupun seminar tentang anemia dalam rangka pencegahan dan penanggulangan anemia oleh pihak universitas.

\section{DAFTAR PUSTAKA}

1. Kemenkes RI. Profil Kesehatan Indonesia Tahun 2014. Jakarta : Kemenkes RI.

2. Bakta IM, Pendekatan Terhadap Pasien Anemia. Penyunting : Sudoyo AW, Bambang Setiyohadi, Idrus Alwi, Marcellus Simadibrata K, Siti Setiati. Buku Ajar Ilmu Penyakit Dalam. edisi IV, jilid II. Jakarta: Pusat Penerbitan Ilmu Penyakit Dalam FK UI; 2006.p.622-623.

3. Arisman MB. Gizi dalam Daur Kehidupan. Jakarta : Penerbit Buku Kedokteran EGC; 2002. p.145-147.

4. Aziz S. Kekurangan Zat Besi dan Anemia. Majalah Kesehatan Departemen Kesehatan Republik Indonesia No 147. Jakarta : Depkes RI; 1996

5. Permaesih D, Herman S. Faktor-faktor yang mempengaruhi anemia pada remaja. Buletin Penelitian Kesehatan. eISSN:2338-3453, Vol:33, No:4, 2005:162-171

6. Castro $\mathrm{R}$, et al. Iron deficiency anemia in adolescent: a literature review. Nutrition Hospitalaria. ISSN:02121611, 2014;29(6) 1240-1249

7. Tim Penulis Poltekkes Depkes Jakarta I. Kesehatan Remaja Problem dan Solusinya. Jakarta: Penerbit Salemba Medika;2010.p.25-26

8. Profil Klinik UIN Sunan Ampel Tahun 2015. Surabaya

9. Laporan Tahunan Klinik UIN Sunan Ampel Tahun 2014. Surabaya

10.Laporan Tahunan Klinik UIN Sunan Ampel Tahun 2015. Surabaya

11.Notoatmodjo S. Metodologi Penelitian Kesehatan. PT. Rineka Cipta, Jakarta, 2005.

12. Sugiyono. 2010. Statistika untuk Penelitian. Bandung: Alfabeta. 